\title{
Characterisation of Tilia pollen seasons in 2018-2019
}

\author{
Aneta Sulborska', Elżbieta Weryszko-Chmielewska', Krystyna Piotrowska-Weryszko', Małgorzata Puc², \\ Monika Ziemianin ${ }^{3}$, Kazimiera Chłopek ${ }^{4}$, Grzegorz Siergiejko5, Dariusz Jurkiewicz ${ }^{6}$, Piotr Rapiejko ${ }^{6}$ \\ ${ }^{1}$ Department of Botany and Plant Physiology, University of Life Sciences in Lublin, Poland \\ ${ }^{2}$ Institute of Marine \& Environmental Sciences, University of Szczecin, Poland \\ ${ }^{3}$ Department of Clinical and Environmental Allergology, Medical College, Jagiellonian University, Cracow, Poland \\ ${ }^{4}$ Department of Paleontology and Stratigraphy, Faculty of Earth Sciences, University of Silesia, Poland \\ ${ }_{5}^{5}$ Pediatrics, Gastroenterology and Allergology Department, University Children Hospital, \\ Medical University of Bialystok, Poland \\ ${ }^{6}$ Department of Otolaryngology with Division of Cranio-Maxillo-Facial Surgery in Military Institute of Medicine,
} Warsaw, Poland

\begin{abstract}
:
Literature reports suggest that Tilia pollen exhibits low or moderate allergenicity. The aim of the study was to compare the pollen seasons of this taxon in seven Polish cities in 2018 and 2019. The aerobiological research stations were located in Bialystok, Cracow, Lublin, Piotrkow Trybunalski, Sosnowiec, Szczecin, and Warsaw. Aerosol samples were collected with the volumetric method using Burkard or Lanzoni pollen samplers. The length of the pollen season was determined using the $95 \%$ method. The earliest onset of the Tilia pollen season was noted in Cracow in both years of the study. In 2018, it began already in May. The highest concentrations of lime pollen grains were recorded in Lublin, whereas the lowest values were reported from Bialystok and Cracow. The maximum daily Tilia pollen concentration was recorded in most of the measurement sites between June $6^{\text {th }}$ and June $11^{\text {th }}$ in 2018 and between June $16^{\text {th }}$ and June $24^{\text {th }}$ in 2019. The annual pollen grain sum in both study years was the highest in Lublin $(971,844)$, whereas the lowest values were noted in Bialystok $(85,102)$ and Cracow $(111,75)$. The concentrations of Tilia pollen in Lublin in 2018 and 2019 were several times higher than the mean values recorded in this city in 2001-2017. The allergen index calculated for Tilia trees growing in the centre of Lublin indicates a moderate allergenic threat posed by the pollen of this taxon to the residents of the city.
\end{abstract}

Key words: pollen concentration, allergenicity, Tilia, 2018, 2019

$\mathrm{P}$ ollen monitoring conducted in Poland involves measurements of lime pollen in many locations in each season. Lime trees grow in the temperate zone of the northern hemisphere [1]. Many lime species are planted in urban greenery designs along streets and in gardens, parks, and squares [2, 3]. In Poland, there are only two species occurring in natural habitats: Tilia cordata and T. platyphyllos. T. cordata grows in mixed forests and is more common than T. platyphyllos, which requires calcareous substrates [1]. Both these species are often planted in urban areas. Many lime specimens in many Polish cities come from the 1960s, as planting of this species was encouraged at that time [4].
Trees from the genus Tilia can be pollinated by insects (entomophily) and by wind (anemophily), depending on the weather conditions. Anemophily plays an important role in bad weather conditions and in the absence of insects $[5,6]$.

In sensitive individuals, Tilia pollen may cause allergies with such symptoms as rhinoconjunctivitis and cough [7]. The allergenicity of the pollen of this taxon is regarded as low [7] or moderate [4, 8, 9]. Since lime trees are often used in urban plantings in Europe, the allergenic index value has been calculated for these species, and it indicates that these trees are moderately allergenic $[9,10]$. 
Aim

The aim of present study was to compare lime pollen season in 7 cities of Poland in 2018-2019.

\section{Material and method}

The material used in the study was provided by monitoring of airborne lime pollen grains in Bialystok, Cracow, Lublin, Piotrkow Trybunalski, Sosnowiec, Szczecin, and Warsaw. Aerosol samples were collected with the volumetric method using Burkard or Lanzoni pollen samplers. Observations of microscopic preparations in a 7-day cycle with assessment of 24-hour periods were carried out in four longitudinal strips. The length of the pollen season was determined with the $95 \%$ method. The date of the pollen season onset was determined after recording $2.5 \%$ of the seasonal cumulative pollen count, while the end of the pollen season was identified after counting $97.5 \%$ of pollen grains.

The pollen grain concentrations were expressed as the number of pollen grains in $1 \mathrm{~m}^{3}$ of air per day $\left(\mathrm{P} / \mathrm{m}^{3}\right)$. The maximum daily concentration, peak date, and annual pollen grain sum were established for each measurement site.

To determine the degree of allergenicity of the lime trees growing in the centre of Lublin, the allergen index value was calculated according to Hruska [11] and Mrđan et al. [9].
Results

\section{Season 2018}

In 2018, the earliest onset of the lime pollen season was noted in Cracow, i.e. already on May $23^{\text {th }}$; in a majority of the measurement sites, the season started between May $29^{\text {th }}$ and June $1^{\text {st }}$ (tab. 1). The end of the pollen season in the analysed cities was noted within a longer period between June $30^{\text {th }}$ and July $24^{\text {th }}$. The earliest end of the lime pollen season was recorded in Cracow, whereas the latest date was noted in Bialystok. The length of the pollen season in most cities ranged from 35 to 39 days, while longer seasons were recorded in Szczecin (43 days) and Bialystok (56 days) (tab. 1).

The highest concentrations of lime pollen were noted in Lublin, with a maximum of $243 \mathrm{P} / \mathrm{m}^{3}$. In the other cities, the maximum daily concentrations were in the range of 9-36 $\mathrm{P} / \mathrm{m}^{3}$, with the lowest value registered in Bialystok and Cracow (tab. 1). The peak value was recorded in early June (June $6^{\text {th }}-9^{\text {th }}$ ) in Piotrkow Trybunalski, Cracow, and Lublin, in the mid-June period (June $11^{\text {th }}$ ) in Bialystok, Szczecin, and Warsaw, and at the end of the month (June 21 ${ }^{\text {st }}$ ) in Sosnowiec (tab. 1, figs 1-7).

The annual sum of Tilia pollen grain had the highest value in Lublin (971). In the other cities, it was in the range of 85-431, with the lowest value in Bialystok (tab. 1). In 2018, the mean value of the annual pollen grain sum from the 7 cities was 331

Table 1. Characteristics of Tilia pollen seasons in 2018 and 2019 years.

\begin{tabular}{|c|c|c|c|c|c|c|}
\hline \multirow{2}{*}{ Site } & \multicolumn{2}{|c|}{ Pollen season period by the $95 \%$ method (days) } & \multicolumn{2}{|c|}{ Peak value $\left[\mathrm{P} / \mathrm{m}^{3}\right]$ and peak date } & \multicolumn{2}{|c|}{ Annual pollen sum } \\
\hline & 2018 & 2019 & 2018 & 2019 & 2018 & 2019 \\
\hline Bialystok & $\begin{array}{c}30.05-24.07 \\
(56)\end{array}$ & $\begin{array}{c}9.06-10.07 \\
(32)\end{array}$ & $\begin{array}{c}9 \\
11.06\end{array}$ & $\begin{array}{c}11 \\
21.06\end{array}$ & 85 & 102 \\
\hline Cracow & $\begin{array}{c}23.05-30.06 \\
(39)\end{array}$ & $\begin{array}{c}5.06-16.07 \\
(42)\end{array}$ & $\begin{array}{c}9 \\
8-9.06\end{array}$ & $\begin{array}{c}6 \\
24.06\end{array}$ & 111 & 75 \\
\hline Lublin & $\begin{array}{c}31.05-4.07 \\
(35)\end{array}$ & $\begin{array}{c}12.06-17.07 \\
(36)\end{array}$ & $\begin{array}{l}243 \\
9.06\end{array}$ & $\begin{array}{c}150 \\
16.06\end{array}$ & 971 & 844 \\
\hline Piotrkow Trybunalski & $\begin{array}{c}29.05-6.07 \\
(39)\end{array}$ & $\begin{array}{c}8.06-7.07 \\
(30)\end{array}$ & $\begin{array}{c}35 \\
6.06\end{array}$ & $\begin{array}{c}31 \\
21.06\end{array}$ & 431 & 279 \\
\hline Sosnowiec & $\begin{array}{c}30.05-5.07 \\
(37)\end{array}$ & $\begin{array}{c}12.06-6.07 \\
(25)\end{array}$ & $\begin{array}{c}36 \\
21.06\end{array}$ & $\begin{array}{c}13 \\
20.06\end{array}$ & 182 & 124 \\
\hline Szczecin & $\begin{array}{c}1.06-13.07 \\
(43)\end{array}$ & $\begin{array}{c}12.06-18.07 \\
(37)\end{array}$ & $\begin{array}{c}30 \\
11.06\end{array}$ & $\begin{array}{c}49 \\
20.06\end{array}$ & 250 & 428 \\
\hline Warsaw & $\begin{array}{c}31.05-5.07 \\
(36)\end{array}$ & $\begin{array}{c}11.06-9.07 \\
(29)\end{array}$ & $\begin{array}{c}25 \\
11.06\end{array}$ & $\begin{array}{c}27 \\
24.06\end{array}$ & 284 & 185 \\
\hline
\end{tabular}




\section{Season 2019}

In 2019, the onset of the lime pollen season was noted in early June $\left(5^{\text {th }}-9^{\text {th }}\right)$ in some cities (Cracow, Piotrkow Trybunalski, Bialystok) and in the second 10-day period in the other cities (June $11^{\text {th }}$ or $12^{\text {th }}$ ) (tab. 1). The length of the pollen season varied from 25 to 42 days. The end of the pollen season was recorded in early $\left(6^{\text {th }}-10^{\text {th }}\right)$ or mid $\left(16^{\text {th }}-18^{\text {th }}\right)$ July. The highest maximum daily concentration, i.e. $150 \mathrm{P} / \mathrm{m}^{3}$, was reported from Lublin. The value of this parameter in the other cities was in the range of 6-49 $\mathrm{P} / \mathrm{m}^{3}$. The earliest peak date was recorded in Lublin (June $16^{\text {th }}$ ), while the other measurement sites showed a peak between June $20^{\text {th }}$ and $24^{\text {th }}$ (tab. 1, figs $1-7$ ). The annual pollen grain sum reached the highest value in Lublin (844), followed by Szczecin (428) and Piotrkow Trybunalski (279).
The mean annual pollen grain sum calculated from the results obtained from the 7 cities in 2019 was 291.

\section{Comparison of pollen seasons 2018 and 2019}

In 2018, the onset of the lime pollen season was noted 10-13 days earlier than in 2019. The average length of the lime pollen season in Poland was 41 days in 2018 and 33 days in 2019 (tab. 1).

The peak date in the compared years was recorded almost at the same time (June $21^{\text {st }}$ and $20^{\text {th }}$ ) only in Sosnowiec. In the other cities in 2019, it was noted 7-15 days later than in 2018. The mean annual pollen grain sum and the peak value were slightly higher in 2018 than in 2019, i.e. by 40 and $14 \mathrm{P} / \mathrm{m}^{3}$, respectively (tab. 1, figs 1-7).

The mean annual pollen sums in each city in 2018 and 2019 are presented in fig. 8. The data indicate

Figure 1. Tilia pollen concentrations in Bialystok in 2018-2019.

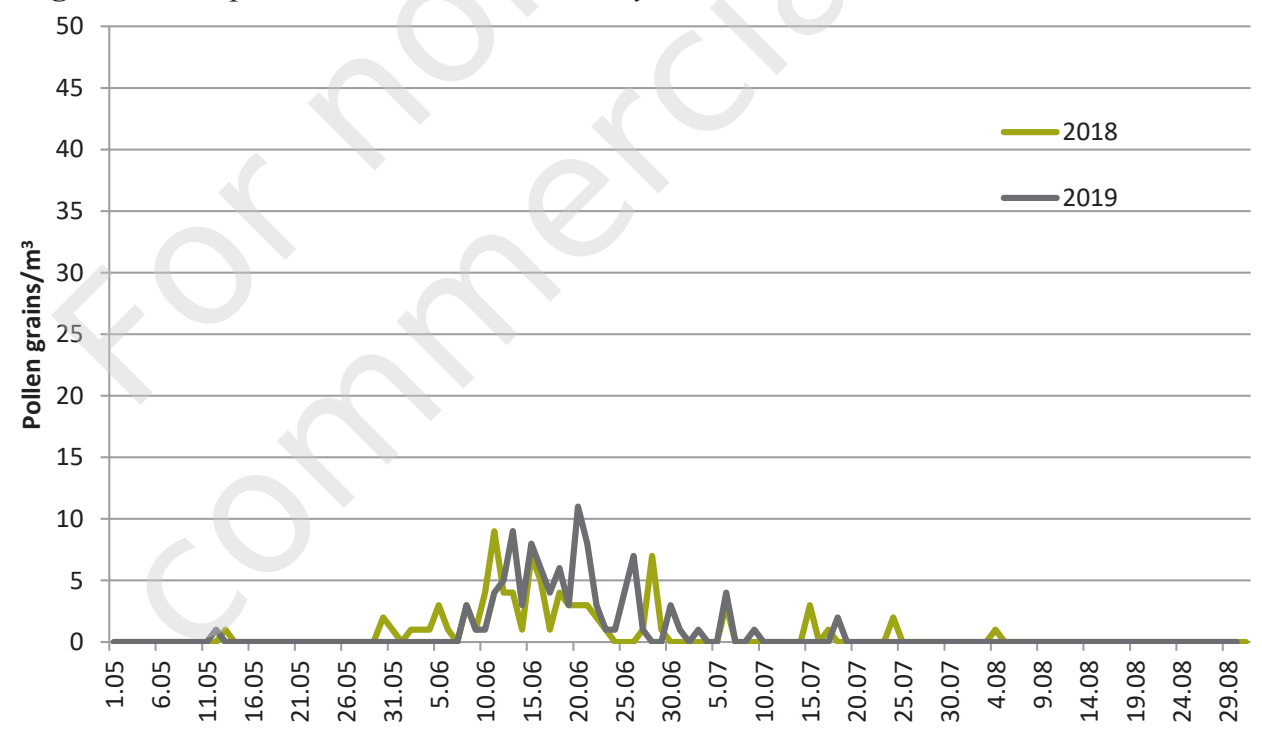

Figure 2. Tilia pollen concentrations in Cracow in 2018-2019.

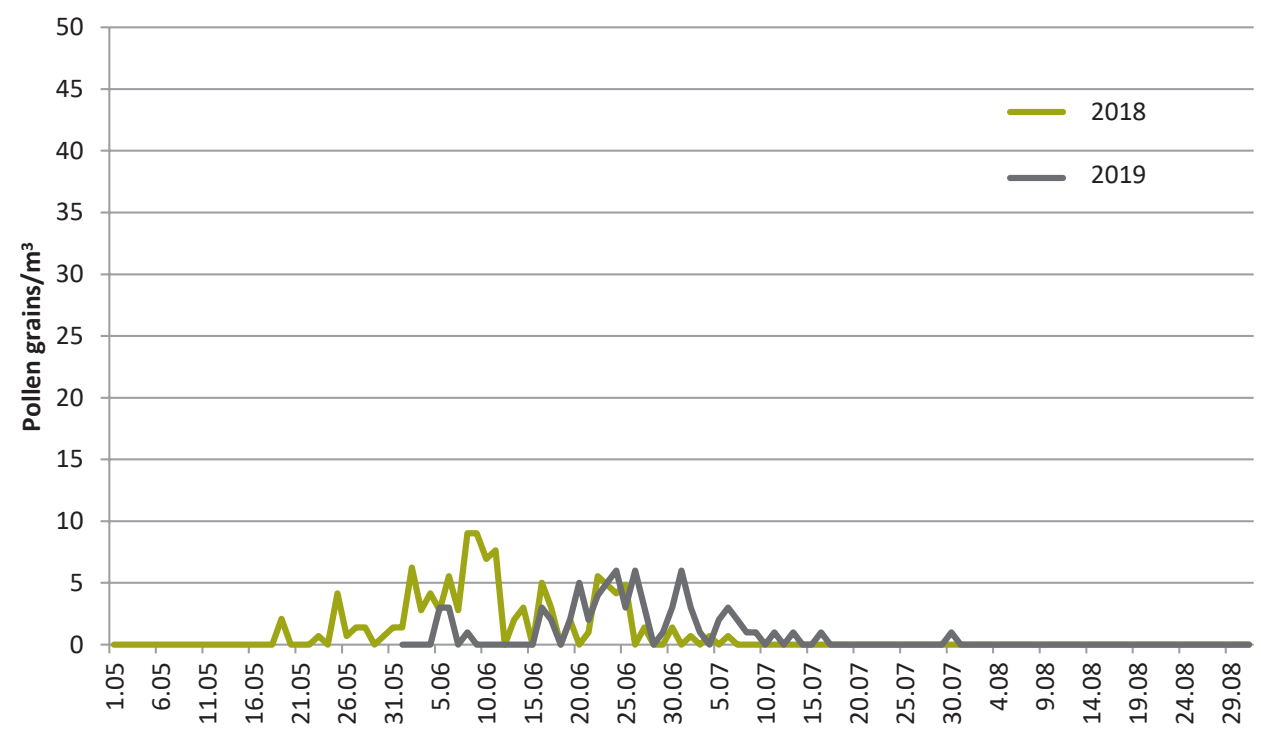


Figure 3. Tilia pollen concentrations in Piotrkow Trybunalski in 2018-2019.

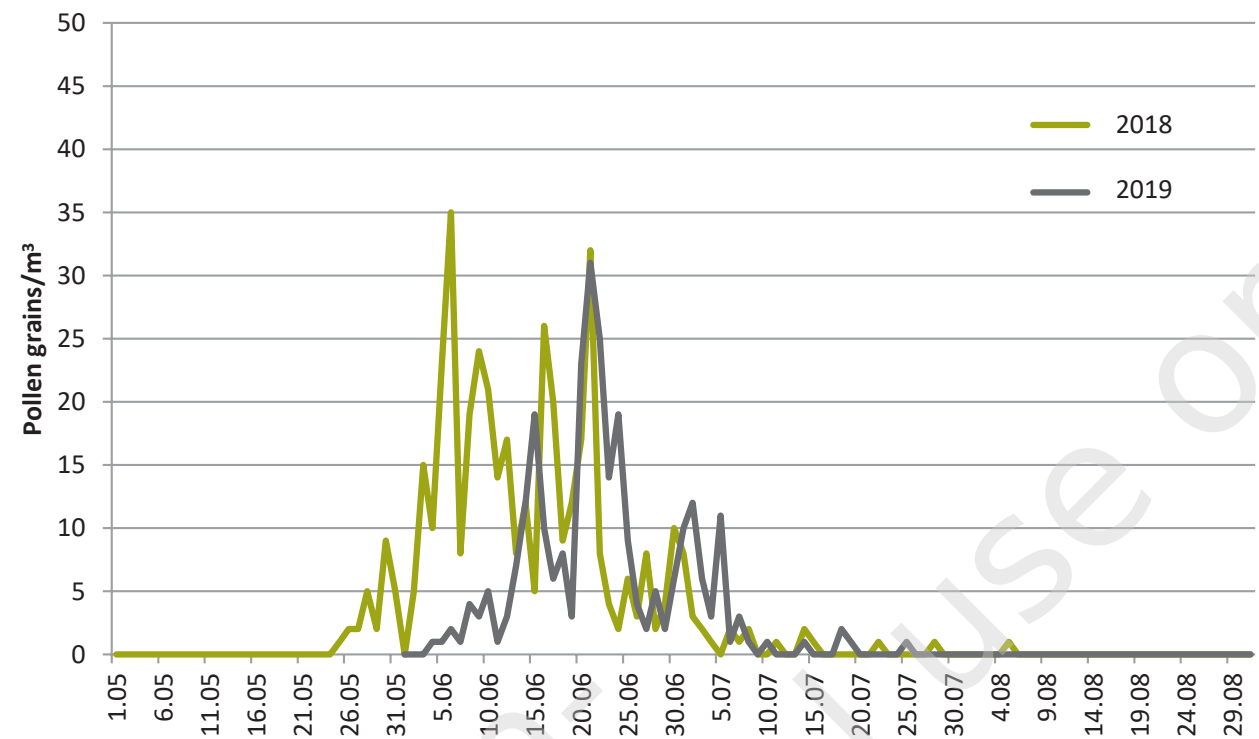

Figure 4. Tilia pollen concentrations in Sosnowiec in 2018-2019.

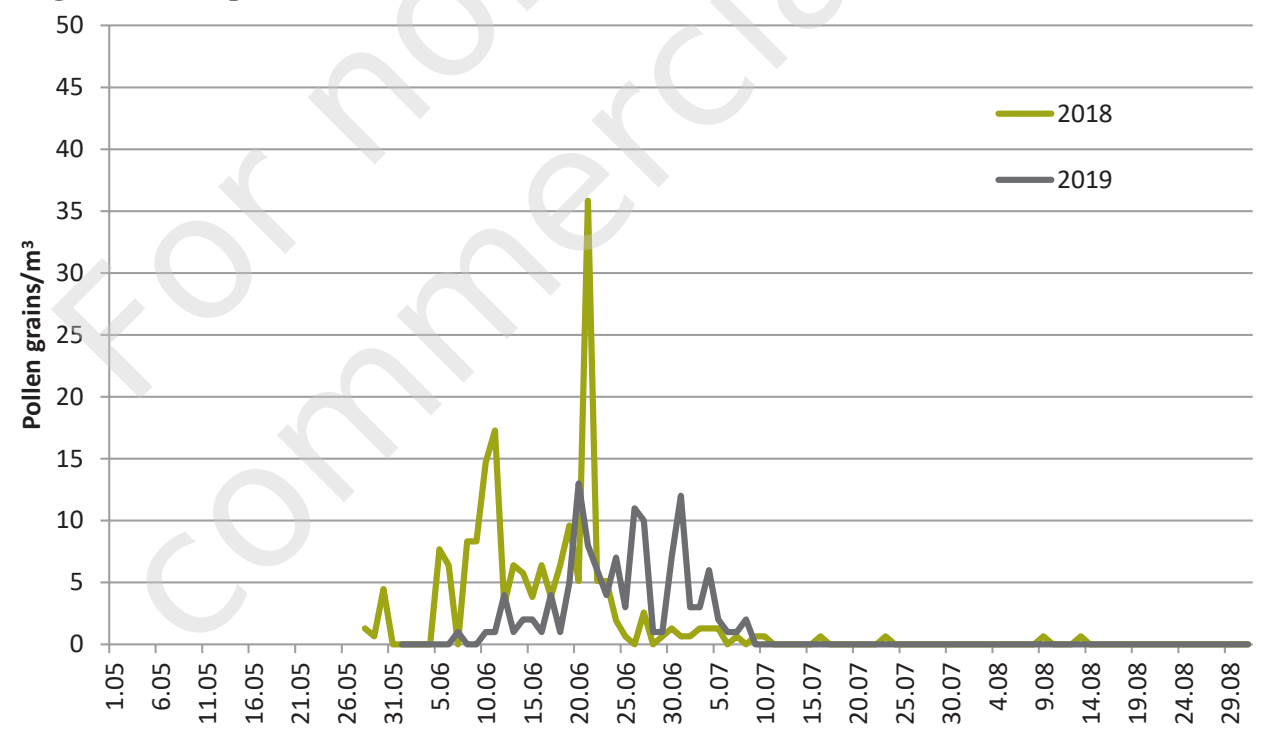

Figure 5. Tilia pollen concentrations in Szczecin in 2018-2019.

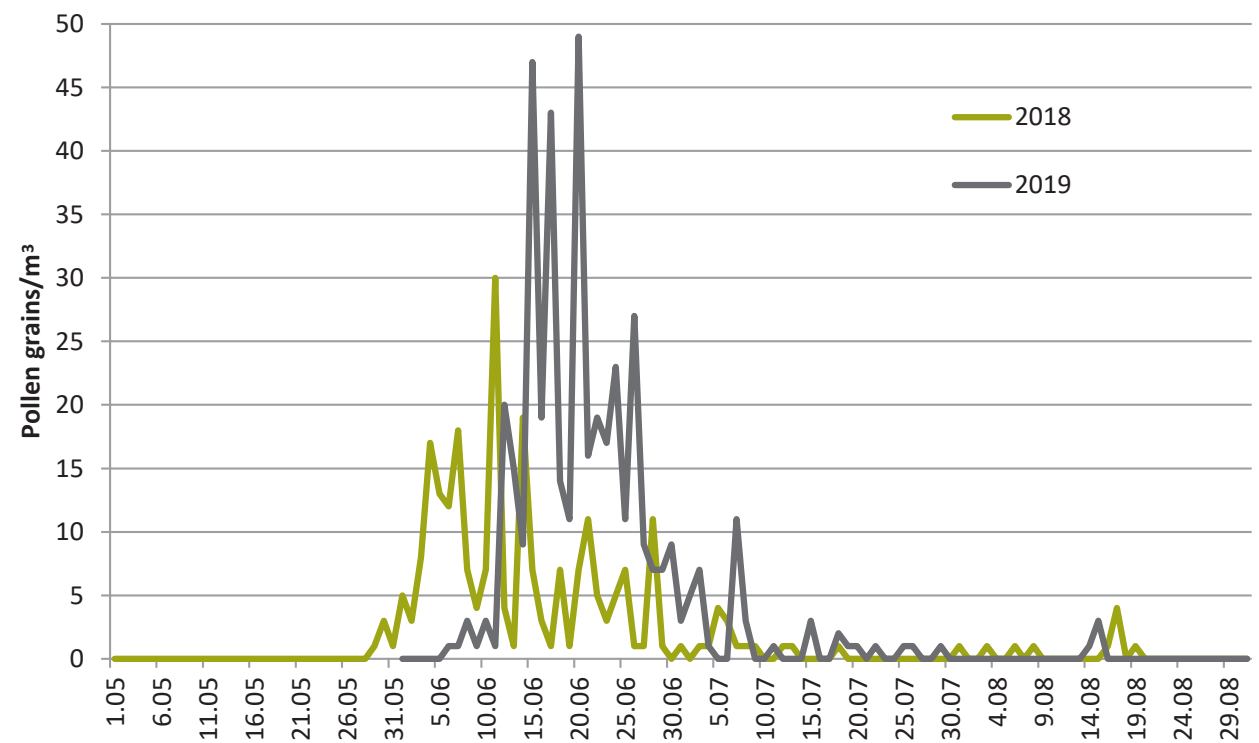




\section{MEDIGAL AEROBIOLOGY}

Figure 6. Tilia pollen concentrations in Warsaw in 2018-2019.

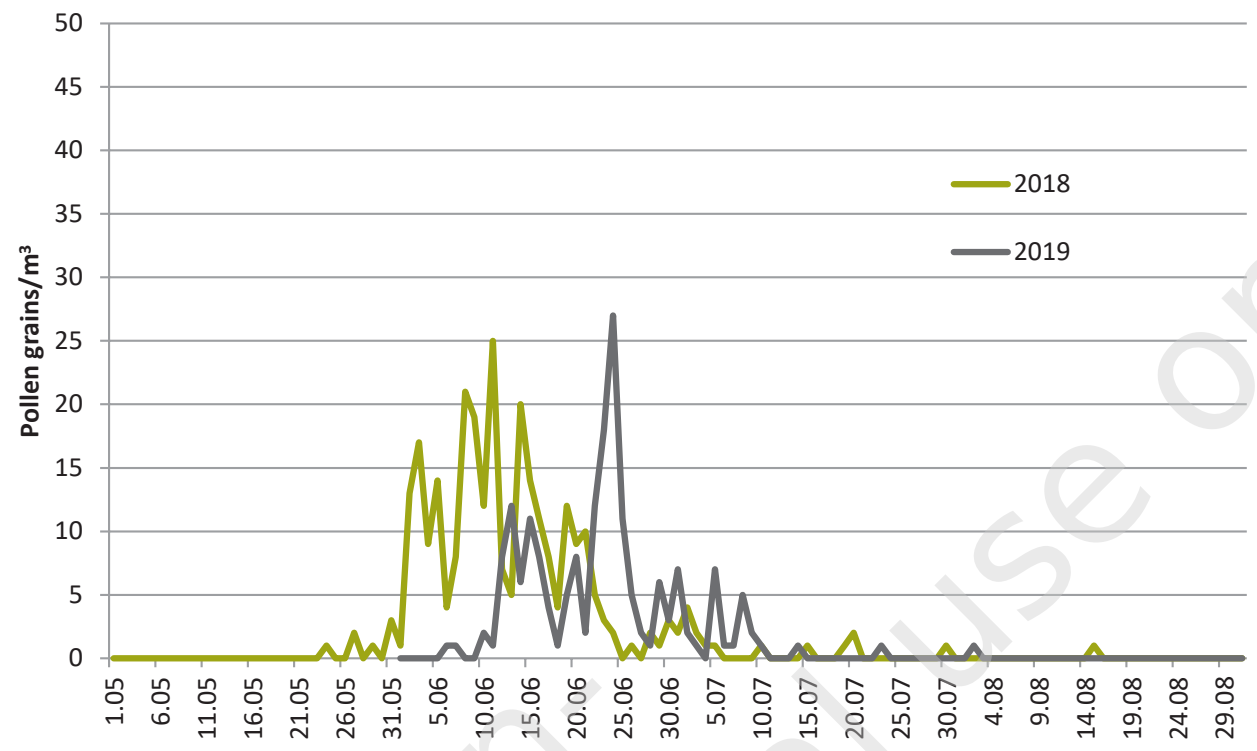

Figure 7. Tilia pollen concentrations in Lublin in 2018-2019.

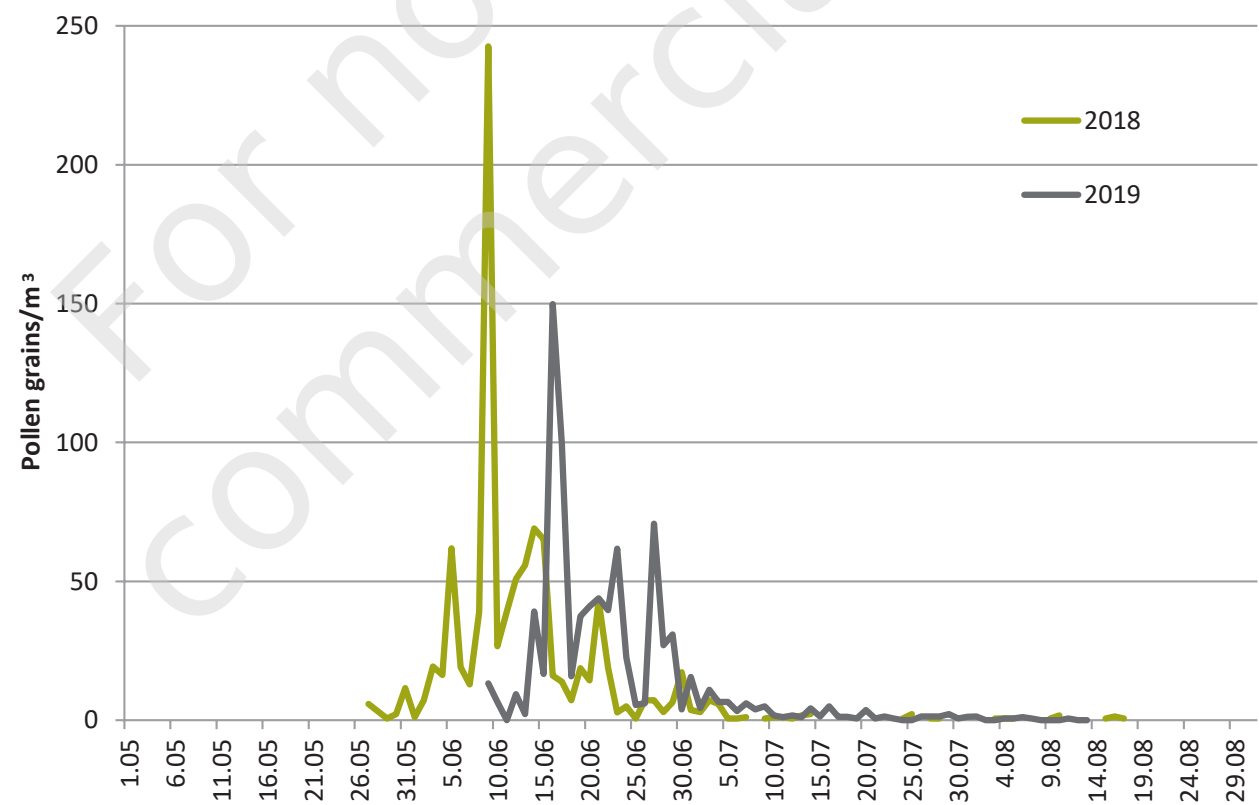

Figure 8. Mean annual pollen sum in 2018-2019 in 7 cities in Poland.

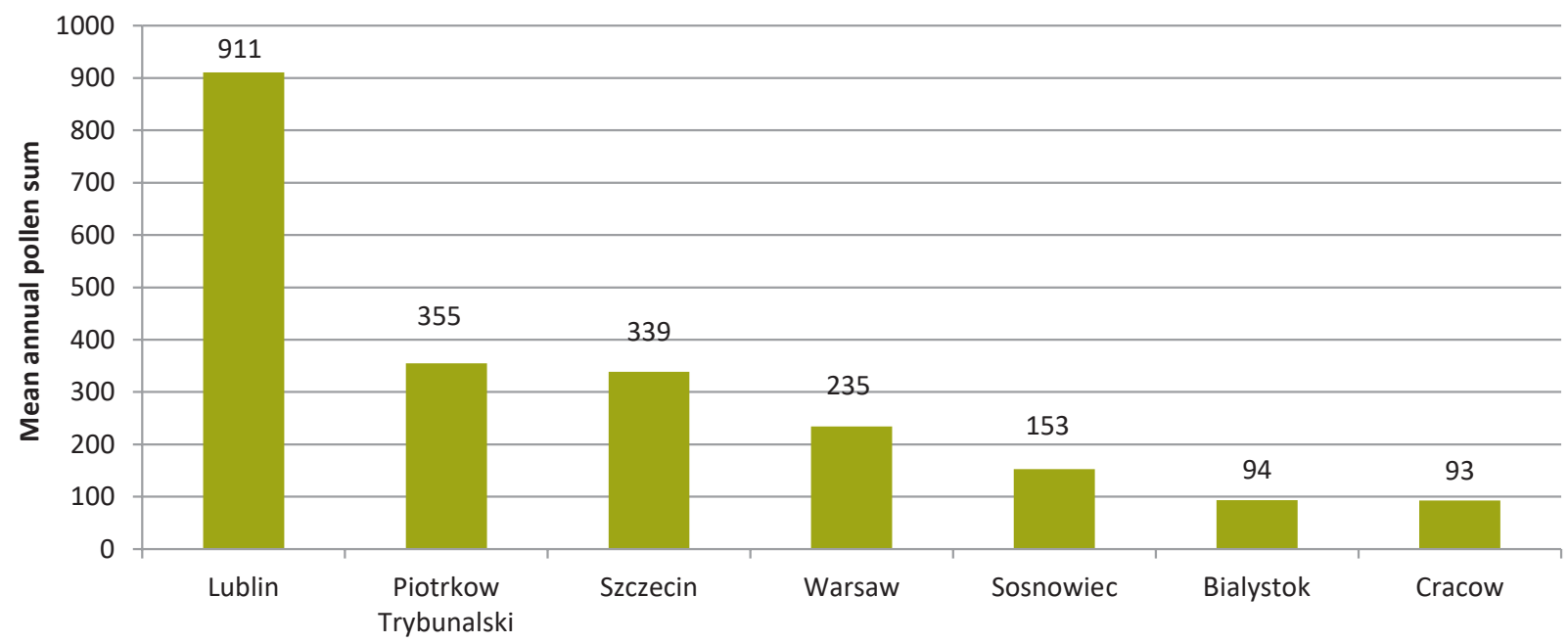


that the value of this parameter in Lublin differs significantly from those calculated for the other cities and is approximately 2.5 -fold higher than the value reported from Piotrkow Trybunalski and Szczecin.

We calculated the allergen index value (AI) for the lime trees growing in the Srodmiescie District of Lublin, which includes 4 parameters: the life cycle, phenanthesic period, cross-reactivity, and abundance of plants. The AI value was 6 , which indicates that the lime trees in this part of Lublin are moderately allergenic.

\section{Discussion}

In 2018-2019, the Tilia pollen season in the measurement sites in Poland lasted on average 41 and 33 days. The overall lime flowering period cover 4-5 weeks from June to July. Individual species flower for 10-17 days, depending on the weather conditions $[3,12,13]$. The length of the pollen season is therefore similar to the length of lime flowering. Previous studies have shown that certain lime species always flower in the same order, with the earliest onset of flowering of Tilia platyphyllos [13].

The graphic representations of Tilia pollen seasons in the analysed cities in a 2-year period shown in this study are characterised by many peaks. These results correspond with earlier studies carried out in Lublin in 2016-2018, where the peaks in multimodal graphs corresponded with the periods of full flowering of various lime species [13]. The comparison of the results of phenological and aerobiological studies carried out in Lublin shows that the presence of the greatest amounts of air-borne Tilia pollen coincides with Tilia cordata flowering [13].

In 2018, the lime pollen season began extremely early, i.e. in May, in most measurement sites. In the Lublin conditions, this was probably associated with the temperatures recorded in April and May, which were several degrees higher than over the previous 17 years [13].

In 2018 and 2019, significantly greater amounts of Tilia pollen grains were recorded in Lublin than in the other cities covered by the aerobiological tests. In the Lublin Srodmiescie District, where the measurement site is located, there are approximately 220 Tilia cordata and 40 Tilia platyphyllos trees [14]. There are many lime trees growing along the streets adjacent to the building where the pollen sampler is located; hence, Tilia pollen is more abundantly represented in the pollen spectrum of Lublin in comparison with the other cities.

In Lublin, the mean annual Tilia pollen sums in 2018 and 2019 were several times higher (911) than the mean value (283) reported from Lublin in 2001-2014 [12]. This may have been caused by the extremely favourable weather conditions prevailing in the recent years.

In terms of their allergenic pollen production, trees growing in urban greenery are divided into three groups having high, moderate, or low potential $[9,11]$. In the present study, we showed that the lime pollen in the centre of Lublin is moderately allergenic, as indicated by the allergen index $=6$. A similar level of allergenicity (5.5) of three Tilia species has been demonstrated in Novi Sad (Serbia) [9].

The available literature provides no data showing the threshold values for lime pollen to induce clinical symptoms. Therefore, we believe that each patient with suspected allergy to lime pollen allergens should be approached individually.

\section{Conclusions}

1. The onset of the lime pollen season in 2018 was recorded very early, i.e. already during the last 10 days of May.

2. Both in 2018 and in 2019, the earliest onset of the Tilia pollen season was recorded in Cracow, and the latest date was noted in Szczecin and Lublin.

3. The highest values of the annual Tilia pollen sum were recorded in Lublin in both study years, which is probably associated with the presence of many lime trees along the streets in the district where the aerobiological measurement site is located.

4. The calculated allergen index value for the lime trees growing in the Lublin Srodmiescie District indicates that they are moderately allergenic to the residents.

\section{References}

1. Szweykowska A, Szweykowski J (eds). Stownik botaniczny. Wiedza Powszechna, Warszawa 2003.

2. Seneta W, Dolatowski J. Dendrologia. Wydawnictwo Naukowe PWN, Warszawa 2008.

3. Weryszko-Chmielewska E, Sadowska D. The phenology of flowering and pollen release in four species of Linden (Tilia L.). J Apic Sci 2010, 54(2): 99-108.

4. Kuchcik M, Dudek W, Btażejczyk K et al. Two faces to greenery on housing estates-mitigating climate but aggravating allergy. A Warsaw case study. Urban For Urban Green 2016, 16: 170-181.

5. Proctor M, Yeo P, Lack A. The Natural History of Pollination. Harper Collins Publishers, London, Glasgow, Sydney, Auckland, Toronto, Johannesburg 1996. 
6. Willmer P. Pollination and Floral Ecology. Princeton University Press, Princeton and Oxford 2011.

7. Mur P, FeoBrito F, Lombardero M et al. Allergy to linden pollen (Tilia cordata). Allergy 2001, 56: 457-458.

8. Igić R, Boža P, Anačkov $G$ et al. Allergenic plants in city of Novi Sad; Efflorescence calendar of allergenic plants. In: Veskovic M (ed). Atlas of Allergenic Plants in City of Novi Sad. University of Novi Sad, Faculty of Sciences 2005.

9. Mrđan S, Ljubojević M, Orlović S et al. Poisonous and allergenic plant species in preschool's and primary schools's yard in the city of Novi Sad. Urban For Urban Green 2017, 25: 112-119.

10. Cariñanos P, Casares-Porcel M, Quesada-Rubio JM. 2014. Estimating the allergenic potential of urban Green spaces: A case-study in Granada, Spain. Landscape Urban Plan 2014, 123: 134-144. DOI: 10.1016/j.landurbplan.2013.12.009.

11. Hruska K. Assessment of urban allergophytes using an allergen index. Aerobiologia 2003, 19(2): 107-111.

12. Dąbrowska A, Piotrowska-Weryszko K, Weryszko-Chmielewska E et al. Flowering phenology of selected linden (Tilia L.) taxa in relations to pollen seasons. J Apic Sci 2016, 60(20): 193-207.

13. Weryszko-Chmielewska E, Piotrowska-Weryszko K, Dąbrowska A. Response of Tilia sp. L to climate warming in urban conditions - phenological and aerobiological studies. Urban For Urban Green 2019, 43(2019): 126369.

14. Dąbski M, Oleś A, Parzymies M. Drzewa i krzewy w śródmieściu miasta Lublina. Zeszyty Problemowe Postępów Nauk Rolniczych 2006, 510: 127-135.

ORCID

A. Sulborska - ID - orcid.org/0000-0002-7720-0719

E. Weryszko-Chmielewska - ID - orcid.org/0000-0001-8410-2757

K. Piotrowska-Weryszko - ID - orcid.org/ 0000-0003-3827-3218

M. Puc - ID - orcid.org/0000-0001-6734-9352

M. Ziemianin - ID - orcid.org/ 0000-0003-4568-8710

G. Siergiejko - ID - orcid.org/0000-0003-4084-8332

D. Jurkiewicz - ID - orcid.org/0000-0003-3729-2679

P. Rapiejko - ID - orcid.org/ 0000-0003-3868-0294

Author's contributions:

Sulborska A: 40\%; other Authors: $7.5 \%$ each.

Conflict of interests: The authors declare that they have no competing interests.

Ethics: The contents presented in this paper are compatible with the rules the Declaration of Helsinki, EU directives and standardized requirements for medical journals.

Corresponding author:

\section{Aneta Sulborska, PhD}

Department of Botany and Plant Physiology, University of Life Sciences in Lublin 20-950 Lublin, Akademicka 15 e-mail: aneta.sulborska@up.lublin 